Marquette University

e-Publications@Marquette

Theology Faculty Research and Publications

Theology, Department of

$5-1-2010$

Caritas in Veritate and Africa's Burden of (Under)Development

Agbonkhianmeghe E. Orobator

Marquette University, agbonkhianmeghe.orobator@marquette.edu

Published version. Theological Studies, Vol. 71, No. 2 (May 2010): 320-334. DOI. (c) 2010

Theological Studies, Inc. Used with permission. 


\title{
CARITAS IN VERITATE AND AFRICA'S BURDEN OF (UNDER)DEVELOPMENT
}

\author{
Agbonkhianmeghe E. Orobator, S.J.
}

\begin{abstract}
Providing a critical reading of Pope Benedict's Caritas in veritate from an African perspective, the note examines several key issues in the encyclical to determine their relevance to the situation of development and underdevelopment in Africa. The note also points out some omissions and troubling situations regarding the role of women in development and the contribution of religion to development, and calls for a careful nuancing of the theological and philosophical underpinnings of the encyclical.
\end{abstract}

$\mathrm{L}$ OOKING AT A KING'S MOUTH," says an African proverb, “you'd think he never sucked at his mother's breast!" Reading Pope Benedict XVI's encyclical Caritas in veritate (2009) on integral human development elicits wonder about whether the pope had anything in mind other than European Catholicism. He does not mention Africa by name, preferring to deal in general terms with the multifaceted and complex theme of development. In truth, however, Caritas in veritate speaks poignantly to the contemporary situation of Africa. Set against the backdrop of the encyclical's primary theme, Africa limns a pathetic profile in most of its countries' checkered attempt to achieve the coveted status of "developed" countries.

Judging from the Human Development Index (HDI) Report 2009, on a global scale Africa lags painfully behind relative to all the indexes of development. ${ }^{1}$ The history of development on the Continent bears a static

Agbonkhianmeghe E. Orobator, S.J., received his Ph.D. from the University of Leeds and is currently provincial superior of the Eastern Africa Province of the Society of Jesus, as well as lecturer in theology at Hekima College Jesuit School of Theology. Specializing in ecclesiology and ethics, his recent publications include: Faith Doing Justice: A Manual for Social Analysis, Catholic Social Teachings, and Social Justice, with Elias O. Opongo (2007); "Method and Context: How and Where Theology Works in Africa," in Shaping a Global Theological Mind, ed. Darren C. Marks (2008); Theology Brewed in an African Pot (2008); and "Church, State, and Catholic Ethics: the Kenyan Dilemma," Theological Studies 70.1 (2009). He is preparing to edit a volume on the second African synod.

1 UN Development Program, Human Development Report 2009, http://hdr.undp. org/en/reports/global/hdr2009/ (this and all other URLs cited in this note were accessed February 12, 2010). HDI measures levels of development on a countryby-country basis, using data based on three criteria: longevity and quality of life, 
quality, barely changing from one year to the next. Among 182 countries listed in HDI 2009 league table of development, Africa's top entry, Libya, appears in the 50th place. The next two highest ranking African countries, Tunisia and Gabon, clinch distant 98th and 103rd positions, respectively. At the bottom end of the table, in the category "Low Human Development" comprising 24 countries, except for Timor-Leste and Afghanistan, African countries maintain almost 100 percent dominance. Given this disturbing situation, Benedict's remark about the historical regression and betrayal of the promises and hopes of development aptly expresses the Continent's predicament: "If some areas of the globe, with a history of poverty, have experienced remarkable changes in terms of their economic growth and their share in world production, other zones are still living in a situation of deprivation comparable to that which existed at the time of Paul VI, and in some cases one can even speak of a deterioration" (no. 33). This observation leads to the sobering conclusion that Africa remains confined to the bottom rung of "the development ladder."

It could be argued, as the pope does extensively, that integral human development is neither measurable solely by, nor reducible exclusively to, material, statistical, and technological indexes (nos. 14, 16-17). Only by adducing a complex of criteria, factors, and processes, including the realm of faith, ethics, and morality, can we reasonably assess, evaluate, and generate a robust account of the quality of human life. Thus, understood in human and Christian terms, development represents a constellation of factors channeled toward "the advancement of all men and of the whole man" on the economic, social, political, and religious level (no. 18; see also nos. 13, 21). Yet, without intending a stereotypical portrayal of Africa, on this qualitative level as well, doubts remain about the Continent's fortunes. ${ }^{3}$

access to education, and a decent standard of living. Claude Ake, Democracy and Development in Africa (Washington: Brookings Institution, 1996) 1-17, has argued that in Africa the rhetoric of development is pure ideology dressed as progress. The principal proponents and beneficiaries of this ideology are African elites and their patrons. So absorbing is their quest to attain and retain political power "that everything else, including the quest of development, is marginalized" (16).

2 This concept was proposed by Jeffrey Sachs, The End of Poverty: Economic Possibilities for Our Time (New York: Penguin, 2005); see also Jean-Marc Ela, Afrique, l'irruption des pauvres: Société contre ingérance, pouvoir, et argent (Paris: L'Harmattan, 1994); Tirfe Mammo, The Paradox of Africa's Poverty: The Role of Indigenous Knowledge, Traditional Practices, and Local Institutions-The Case of Ethiopia (Lawrenceville, N.J.: Red Sea, 1999).

${ }^{3}$ In 2001 the international community under the auspices of the United Nations General Assembly created a set of quantitative targets of social and economic development known as Millennium Development Goals (MDGs). With five years to the target date (2015) the rate of progress is slowest in sub-Saharan Africa. 
In his concern to present an articulated and integral understanding of development, Benedict adopts a broad approach. His encyclical's omnibus perspective is at once its merit and its weakness. Generating a "global" account of development precludes a conceptual reductionism that perceives it through the narrow lenses of a limited set of criteria. Yet in trying to avoid a skewed or simplistic understanding, the complex nature of the reality itself means that a penetrating and comprehensive analysis is hardly feasible in a brief, albeit dense, encyclical. The challenge is greater for any attempt to comment on the encyclical. The issues are too wide and too numerous to allow for anything resembling a comprehensive analysis.

This note focuses on a select number of issues treated in Caritas in veritate without claiming to present an exhaustive analysis, from an African perspective, of all the facets of the reality called "development." The selection of items for consideration is guided by how the encyclical throws light on some issues affecting the Continent and how these issues form the basis for a critical analysis of Caritas in veritate. Paramount among them are: the meaning and experience of poverty, the mutation of world ideological systems, environmental concerns, social vices, the contribution of religion to development, and the role of the state. This note also considers some omissions and shortcomings of the encyclical set in the context of Africa.

\section{OF DEVELOPMENT, FREEDOM, AND POVERTY}

Arguably poverty represents the most tangible indicator of the absence of development. Some accounts of development equate Africa with poverty. There are many faces of poverty in Africa. Current analyses indicate a convergence of thought and ideas not only around poverty's causes and effects but also on its variety of forms. ${ }^{4}$ Of particular salience is the notion of anthropological poverty. According to this line of thought, centuries of colonial domination of Africa have resulted in a historical psychological conditioning of Africans that manifests itself as a defeatist mentality, a selfperception incapable of envisioning progress, and perpetual confinement in a straightjacket of misery (see no. 17). ${ }^{5}$

United Nations, The Millennium Development Goals Report 2009, http://unstats.un. org/unsd/mdg/Resources/Static/Products/Progress2009/MDG_Report_2009_En.pdf.

4 Debate continues among development economists and agencies over the precise meaning and measure of poverty. See David Gordon, "The International Measurement of Poverty and Anti-poverty Policies," in World Poverty: New Policies to Defeat an Old Enemy, ed. Peter Townsend and David Gordon (Bristol, UK: Policy, 2002) 53-80; Anthony O'Connor, Poverty in Africa: A Geographical Approach (London: Belhaven, 1991) 21-22.

5 The idea of "anthropological poverty" was first proposed by Engelbeth Mveng, "Impoverishment and Liberation: A Theological Approach for Africa and the 
One can hardly deny the role of anthropology in the overall conception of development or its lack. By insisting on freedom as the fulcrum of development, Benedict strikes a harmonious resonance with proponents of anthropological poverty. ${ }^{6}$ Read from the perspective of Africa, Caritas in veritate suggests that the task of freedom is not confined to the ability to transcend the limitation of nature or the capacity to control the technique and technology of development. Development as freedom embodies the responsibility - or, in the preferred terminology of Caritas in veritate, "vocation"-to liberate masses of Africans from their subservience to a collective oppressive colonial mentality and memory. Left unredeemed, this notion of anthropological poverty creates convenient alibis for the Continent's enduring bondage to situations of underdevelopment (no. 18). Its redeeming grace is the development of freedom.

Furthermore, Benedict identifies and insists on the human person as the core and center of development. The convergence of this position with African ideas and notions about life is so evident it needs no justification. African ethical and anthropological constructs are founded on "the principle of the centrality of the human person" (no. 47). Along with the primacy of the human person come the idea of relationality (no. 55) and the notion of solidarity (no. 58), both of which enable integral development. Human life broadly conceived forms the measure or criterion for assessing and judging the morality of actions of social, economic, and political actors, be they individuals or institutions. Where commitment to the preservation, strengthening, and reinforcement of the life of the human person wanes, the moral status of the actors becomes suspect as dangerous and immoral. ${ }^{7}$ This African framework for ethical reflection converges with the principles of Catholic social teaching, as Benedict's encyclical applies these to global socioeconomic and political systems relative to the meaning of development. Thus a correct understanding of the anthropological dimension of poverty has the triple advantage of, first, recognizing the human agency at the root of (under)development; thereby, second, prioritizing the human person as the measure of development; and finally, recognizing that solutions to poverty, in the form of integral development, serve rather than subvert the deep yearnings and aspirations of the human person. "Only

Third World," in Paths of African Theology, ed. Rosino Gibellini (London: SCM, 1994) 154-65.

${ }^{6}$ This idea is redolent of Amartya Sen's thesis of development as freedom and freedom as development; see Sen, Development as Freedom (New York: Knopf, 1999).

7 "Life" as the foundation of African ethical systems has been explored by Laurenti Magesa, African Religion: The Moral Traditions of Abundant Life (New York: Orbis, 1997); and Bénézet Buzo, Foundations of an African Ethic: Beyond the Universal Claims of Western Morality (Nairobi: Paulines, 2003). 
when it is free can development be integrally human; only in a climate of responsible freedom can it grow in a satisfactory manner" (no. 17).

The foregoing notwithstanding, there is the matter of the historical evolution of poverty. Poverty has not always meant the same thing in Africa. In this perspective the linear conception of development as a mission to rescue Africa from the shackles of poverty, disease, and ignorance assumed in Caritas in veritate (nos. 21, 42) calls for some analytical nuances. If the poor have always been with us, the poor have not always been the same. John Iliffe's work on the history of poverty remains the most comprehensive study of the meaning of poverty in Africa chronologically and diachronically, structurally and theoretically. ${ }^{8}$ His pioneering study leads to the conclusion that from one era to another, the meaning, structure, and experience of poverty cannot be presumed as static or neutral. Accordingly, the contemporary vocabulary of poverty includes the "new poor" and "new forms of poverty" (no. 22) in Africa and elsewhere; the plight of the "new poor" defines new horizons, challenges, and tasks for the notion of integral development. The category of "new poor" includes people infected and affected by HIV/AIDS, those at the receiving end of ecological degradation, ${ }^{9}$ and those forced to flee their land for a variety of reasons. Each of these populations is the focus of theological and ethical debate in Africa. ${ }^{10}$ The idea of new forms of poverty challenges theological ethics in Africa to keep abreast of the rapid evolution of ideas and correlates of poverty and development, and underlines the importance of a multidisciplinary approach to the problem of underdevelopment.

\section{SHIFTING IDEOLOGICAL BLOCS}

Pope Paul VI's encyclical Populorum progressio (1967) stands as an important historical reference point for Caritas in veritate's evaluation of the development of peoples over the last four decades. The latter encyclical proffers "a fresh reading of Populorum Progressio" (no. 10). During the

\footnotetext{
8 John Iliffe, The African Poor: A History (New York: Cambridge University, 1987).

9 In her Unbowed: One Woman's Story (London: William Heinemann, 2006), Kenyan Nobel laureate Wangari Maathai recounts how impoverishment resulted from the destruction of the natural ecosystem of her childhood days. See also David M. Anderson and Vigdis Broch-Due, eds., The Poor Are Not Us: Poverty and Pastoralism in Eastern Africa (Oxford: James Currey, 1999).

${ }^{10}$ See, e.g., Maathai, Unbowed; Agbonkhianmeghe E. Orobator, From Crisis to Kairos: The Mission of the Church in the Time of HIV/AIDS, Refugees, and Poverty (Nairobi: Paulines, 2005); Tim Allen, ed., In Search of Cool Ground: War, Flight, and Homecoming in Northeast Africa (Geneva: UNRISD, 1996); David Hollenbach, ed., Refugee Rights: Ethics, Advocacy, and Africa (Washington: Georgetown University, 2008).
} 
intervening years the world has seen economic systems rise, wane, and fall. The ideological underpinnings, pretensions, and extremities of these systems might mutate as circumstances dictate, but they never completely lose their potent capacity to determine the fate of millions of people who depend on the global economic and financial order. An important framework for the examination of the global geopolitical and economic configuration with regard to its effects on underdeveloped countries is the "so-called opposing blocs" (no. 23).

Pope Benedict assumes the demise of "opposing blocs," but contemporary history provides eloquent testimony to the contrary. In name, the obvious and odious manifestations of the polarization between the capitalist West and the socialist East, such as proxy wars on the continent of Africa, have all but disappeared. Yet insidious manifestations of external manipulation remain decisive for Africa's economic and political predicament, specifically in the sphere of resource extraction. Africa has become the theater of internecine conflicts directly related to the extraction of its natural and mineral resources. Typical examples include the Democratic Republic of Congo, South Sudan, Chad, and Nigeria. While these conflicts appear to be internal matters of nonviable feuding states, the larger picture shows the complicity of erstwhile ideological and geopolitical blocs in search of new energy sources to meet growing domestic demands.

What negates the principles of Catholic social teaching is the tendency for developed countries of the West and the East to pursue their economic interests in Africa at the expense of basic human rights, decent quality of life, and various indicators of development. A correct analysis of the global economic order cannot gloss over this reality without losing its critical edge. In presuming the demise of ideologically opposing blocs, Caritas in veritate's analysis of geopolitical and economic history may placate Western conscience, but not victims of regnant ideologies of exploitation and extraction of the mineral and natural wealth of African countries.

This concern about Africa's natural and mineral wealth evokes the more universal concern for the environment. Dysfunctional models and practices of development pose a threat to "the earth's state of ecological health" (no. 32). Benedict's idea of the human person as the measure, driver, and goal of development is intrinsically connected to the reverence for the means of sustaining human life in the ecological realm: "The way humanity treats the environment influences the way it treats itself, and vice versa" (no. 51). Respect for life also generates a moral duty to protect and care for the natural environment and creation as a whole (see nos. 48, 50). Here notions native to African religious traditions blend well with the seminal idea that the "book of nature" comprises not just the "environmental ecology" but, more critically, the "human ecology" (no. 51), both of which form incontrovertible constants of integral human development. "Just as 
human virtues are interrelated, such that the weakening of one places others at risk, so the ecological system is based on respect for a plan that affects both the health of society and its good relationship with nature" (no. 51).

Caritas in veritate correctly notes the temptation to "view nature as something more important than the human person. This position leads to attitudes of neo-paganism or a new pantheism" (no. 48). Viewed against the backdrop of African indigenous religious traditions, the tendency is to see only an incompatibility of religious purposes vis-à-vis Christianity. African indigenous religious traditions consider the realm of the natural environment as charged with and inhabited by a multiplicity of spirits. Oftentimes indigenous African beliefs that underpin respect for environmental ecology are prejudicially construed as "neopaganism" or "pantheism." This prejudice misses the point.

The pivotal element here is what Bénézet Bujo describes as "interdependence of forces" between the human person and the cosmos that allows each to influence the other. Such is the intensity of this vital connection that "one can only save oneself by saving the cosmos." This approach to "environmental ecology," as Benedict describes it, translates into a uniquely African spirituality and approach to the cosmos or creation where the latter acquires a sacramental dimension as a text inscribed all over with the actions of God who triumphs over death to save both humankind and the cosmos. Worship, praise, and celebration in Africa are suffused with rites and rituals that draw upon nature as a source and an inspiration of liturgical action. ${ }^{11}$

In the context of the encyclical, such a spirituality and ethical imperative of reverence for nature, whether human or environmental, contain a powerful reminder that the duty to protect and preserve "environmental ecology" and "human ecology" derives from their constitution "not only by matter but also by spirit" (no. 48). This understanding obviates the tendency to dismiss African indigenous religions as animist and pagan. These religions concur with Christianity in recognizing creation as "the wonderful result of God's creative activity, which we may use responsibly to satisfy our legitimate needs, material or otherwise, while respecting the intrinsic balance of creation" (no. 48).

\section{CORRUPTION, DEVELOPMENT, AND CATHOLIC SOCIAL TEACHING}

Caritas in veritate strikes a familiar note, albeit perfunctorily, on the problem of corruption: "Corruption and illegality are unfortunately evident in the conduct of the economic and political class in rich countries, both old

11 See Bénézet Bujo, The Ethical Dimension of Community: The African Model and the Dialogue between North and South (Nairobi: Paulines, 1998) 208-25. 
and new, as well as in poor ones" (no. 22). Considering the neutralizing effect of corruption and illegality on the prospects of integral development, especially in Africa, the encyclical's brief treatment of corruption warrants further analysis. There is no suggestion that the problem of corruption is unique to Africa. Yet, just like the human development index, the global measure of levels and perceptions of corruption rank several of Africa's underdeveloped countries among the world's most corrupt countries. ${ }^{12}$ Attention to corruption is generating significant monographs. ${ }^{13}$

New strategies for Africa's development continue "to be weighed down by malfunctions and dramatic problems" (no. 21) related to bribery, sleaze, and tribalism at all levels of social, economic, and political interaction. This point resonates with the encyclical's overall perspective that failure awaits any social, political, or economic system that does not attend to the ethical imperatives of justice, equity, and fairness in the exchange of social, economic, and political goods and services. What solutions does the encyclical offer for dealing with the challenge of corruption in the context of development? It amply references the virtues of solidarity, gratuitousness, and gift. As Michael Czerny notes, "The heart of the encyclical is gift, gratitude, graciousness, and gratuitousness."

Interestingly, viewed from the situation in Africa, a noticeable irony characterizes the emphasis on solidarity, gratuitousness, and gift, at least as these are presented as redemptive virtues in the exercise of political power and the exchange of goods and services. Ironically, Africa is often labeled as corrupt precisely for practicing what Caritas in veritate extols as the economics of communion and affection. This seemingly innocuous system thrives on tightly knit solidarity, mutuality of favors, and gratuity of services with anticipated recompense. It prizes personal relationships over efficiency, rule of law, and public accountability. Given this typically African understanding, ideas of gratuitousness and solidarity would need further nuances before they can be made the basis of a universal principle of economic, social, and political development (see nos. 34-39).

12 See Transparency International, "Corruption Perception Index” (CPI), http:// www.transparency.org/policy_research/surveys_indices/cpi/2009/cpi_2009_table.

13 In addition to the classic study of corruption in Africa by Jean-François Bayart, The State in Africa: The Politics of the Belly (New York: Longman, 1993), recent useful sources include: Michela Wrong, It's Our Turn to Eat: The Story of a Kenyan Whistleblower (New York: HarperCollins, 2009); Peter Anassi, Corruption in Africa: The Kenyan Experience (Victoria, Canada: Trafford, 2004); and Patrick Chabal and Jean-Pascal Daloz, Africa Works: Disorder as Political Instrument (London: International African Institute, 1999).

${ }^{14}$ Michael Czerny, "Papal Encyclical Tells Us to 'Think!' and 'Love!," Catholic Register, August 9-16, 2009. 
Caritas in veritate and John Paul II's Sollicitudo rei socialis presume a common understanding of the notion of solidarity. In situations of desperation, calamity, and impoverishment, or in any situation that threatens survival or the quality of human life, solidarity would represent an essential value of profound ethical import. Yet we may not ignore the possibility that the appeal to the notion of solidarity can assume specific nuances depending on the particular cultural context, the outcome of which may be ethically problematic.

In several parts of Africa, solidarity is expressed in terms of favorable conditions given (gift) to acquaintances, close relatives, and clients. In this case, solidarity represents a carefully delineated and controlled space beyond which gratuity and gift rarely extend. This space is defined by "particularistic and communitarian codes of conduct which have very little in common with the notion of the public good." 15 It has much less in common with the concern for justice, fairness, equity, and common good, which Caritas in veritate presents as constitutive of Catholic social teaching and enabling principles of an articulated and integrated understanding of development (see nos. 2, 5-6). Arguably, the tradition of Catholic social teaching bears significant implications for the situation in Africa. ${ }^{16}$ The tenets of this body of teaching have been quoted and used extensively, especially in pastoral letters emanating from African episcopal conferences and individual ecclesiastics.

Caution is needed when dealing with the situation of Africa. There is a difference between mining Catholic social teaching for proof texts and applying it as a principle of social transformation. Caritas in veritate lauds the transformative qualities of Catholic social teaching, but copious references could conceal the complications arising from the particularities of the contexts to which they are applied. Among African Christians, for example, mention of Catholic social teaching often resembles a reference to an esoteric and arcane rhetoric used to denounce mundane local situations and vices like corruption, illegality, and impunity to no avail. A deeper analysis is needed to decipher, contextualize, and translate "our best kept secret" 17 into a factor of social change and the civilization of exploitative economics and politics in Africa.

15 Chabal and Daloz, Africa Works 100.

${ }^{16}$ For a practical application of the principles of Catholic social teaching to the African context, see Nicholas Otieno, Human Rights and Social Justice in Africa: Cultural, Ethical, and Spiritual Imperatives (Nairobi: All Africa Conference of Churches, 2008); Elias O. Opongo and Agbonkhianmeghe E. Orobator, Faith Doing Justice: A Manual for Social Analysis, Catholic Social Teachings, and Social Justice (Nairobi: Paulines, 2007).

${ }_{17}$ Peter J. Henriot, Edward P. DeBerri, and Michael J. Schultheis, Catholic Social Teaching: Our Best Kept Secret (Maryknoll, N.Y.: Orbis, 2003). 


\section{CARITAS BEGINS AT HOME-OR “DOMESTIC JUSTICE"}

As with papal encyclicals and pastoral letters of episcopal conferences in Africa, Caritas in veritate adopts a didactic and magisterial approach in its treatment of the multiple layers and dimensions of development. This approach or style carries a risk. Granted, the pope does not intend to write a textbook of development economics. The real audience of Benedict's magisterial delivery is urbi et orbi: multinational corporations, international community, governmental, and nongovernmental agencies or corporations. In similar fashion, the church in Africa has developed a remarkable capacity to address ad extra social issues while paying nominal attention to ad intra issues: "A distinguishing feature of Catholic life in the global South," observes John Allen, "is its predominantly ad extra focus. Theologians, bishops, and lay activists tend to be more concerned with how the Church tackles questions such as the relationship with Islam or the alleviation of poverty, rather than 'insider Catholic baseball' such as women's ordination to the priesthood or how power is distributed in the Church." 18 The inherent risk of this approach is the tendency to cast the "world" in an externalized or extroverted mold vis-à-vis a papal magisterium construed as "Mater et magistra"-one external institution addressing another.

In the context of Caritas in veritate the question arises: if development is as integral as Benedict correctly claims it is, at what point does the axis of flaws, ills, and failings of secular and global social, political, and economic realms intersect with that of the community called "church"? The 1971 Synod of Bishops's document, Justitia in mundo, best expresses the immediate concern here: "While the Church is bound to give witness to justice, she recognizes that anyone who ventures to speak to people about justice must first be just in their eyes. Hence we must undertake an examination of the modes of acting and of the possessions and life style found within the Church herself." 19 This ethical prerequisite of "domestic justice" echoes the incisive remarks of Pope Paul VI in his 1975 encyclical, Evangelii nuntiandi, that "modern man listens more willingly to witnesses than to teachers, and if he does listen to teachers, it is because they are witnesses"" (no. 41). Cultural or traditional attitudes that impede integral human development do not reside exclusively within the secular realm; "modes of acting" inimical to integral development can be "found within the Church herself." Thus principles and criteria by which Caritas in veritate criticizes and excoriates social, political, and economic systems could prove useful and apt in evaluating the openness of the community called "church," for

\footnotetext{
18 John L. Allen Jr., The Future Church: How Ten Trends Are Revolutionizing the Catholic Church (New York: Doubleday, 2009) 37.

$19 \mathrm{http}: / /$ catholicsocialservices.org.au/Catholic_Social_Teaching/Justitia_in_Mundo, no. 40 .
} 
example, in the exercise of authority, equality in mission, and attentiveness to the needs of the marginalized, impoverished, and vulnerable.

In the church in Africa, as in the universal church, the concern raised in the preceding paragraph applies to one familiar area, namely, the status and role of women in church and in society. But Caritas in veritate, aside from a passing comment in no. 28 on women, abortion, and sterilization, maintains a deafening silence on the situation of women in the context of development. The United Nations Development Programme firmly establishes awareness about the pivotal role of women and their extreme vulnerability in the global complex of development, particularly in regard to "politics and governance, access to public services, economic opportunities, justice and the distribution of international assistance for development and security." 20 This awareness has been demonstrated beyond question in the context of Africa, where various studies recognize women as engines and catalysts of development. ${ }^{21}$ In addition, global indicators of underdevelopment reveal how they doubly affect women. Africa is a good example of how access to knowledge and a decent standard of living continue to elude the vast majority of women. The disparities and inequities affecting women in "situations of underdevelopment . . . are not due to chance or historical necessity, but are attributable to human responsibility" (Caritas in veritate no. 17). They point up power differentials and vulnerability to local and global trends that reinforce unjust marginalization and oppression of women in Africa. ${ }^{22}$ Two concrete illustrations of this phenomenon readily come to mind.

First, in the context of forced displacement, women fair badly compared to men, not only in the intensity and concentration of numbers, but also when it comes to adequate protection from violence, guaranteeing human rights, and provision for specialized needs such as reproductive, sanitary, and maternal and child health. Second, in the context of HIV and AIDS, statistics demonstrate the gender-specific devastating effects of this disease in Africa and elsewhere. Women bear the brunt of the disease. Considering this situation, women do not and cannot access development on equal terms with men. Additional measures are needed if the justice, solidarity, and equity that Caritas in veritate promotes as vital ingredients of development are to become available for women as well as for men. Presently, in

${ }^{20}$ United Nations Development Programme, Annual Report 2009, http://www. undp.org/publications/annualreport2009/pdf/EN_FINAL.pdf, p. 16.

${ }^{21}$ For a concise historical account of shifting patterns and roles of African women in development, see April A. Gordon, "Women and Development," in Understanding Contemporary Africa, 3rd ed., ed. April A. Gordon and Donald L. Gordon (Boulder, Colo.: Lynne Rienner, 2001) 271-97.

22 Egara Kabaji, Women in Development (Eldoret, Kenya: Zapf Chancery, 1997), examines this issue in relation to women in Kenya. 
church more than in society, this message needs a clearer and more honest articulation. Simply put, in addition to secular society, the message, principle, and goal of development for all ought to resonate deep within the cultural and traditional attitudes and modes of acting of the community called "church." The Second African Synod echoes the poignancy of this point: "Women in Africa make a great contribution to the family, society and the Church with their many talents and resources. However, not only are their dignity and contributions not fully recognized and appreciated, but they are often deprived of their rights." These words ring hollow without "the greater integration of women into Church structures and decisionmaking processes." 23 Charity must also speak its truth to the Church.

\section{THE RELIGION OF (UNDER)DEVELOPMENT}

Caritas in veritate demonstrates the close connection between faith and reason, religion and development. In this encyclical the ideological sparring partner of Benedict XVI is secularism in its various forms, especially atheism and relativism. This duo of "isms" is construed as a principal adversary of venerable and veritable Christian principles. In the context of Western Catholicism the encyclical's analysis relative to these concerns appears impregnable. The picture changes dramatically, however, when the hedges of critical analysis are extended farther and wider to include the context of Africa. The question whether or not "God has a place in the public realm" (no. 56) does not arise on the Continent. What seems to defy logic and require explanation is not the crisis of faith or the absence of religion, but the ubiquity and pervasiveness of religion in Africa. If "Development needs Christians with their arms raised towards God in prayer" (no. 79), then Africa possesses the advantage of numbers and public display of religiosity. The irony, however, surfaces in the fact that in Africa the fortunes of religious faith, affiliation, and practices flourish in inverse proportion to the Continent's economic, social, and political misfortunes. The demographics of religious affiliation constitute the subject of glowing assessments of the astronomical growth of Christianity in Africa. ${ }^{24}$ The question of the relevance of faith to development is posed not from the perspective of the dearth of the former, but precisely because the benefit of the latter

${ }^{23}$ II Coetus specialis pro Africa, "Elenchus finalis propositionum," http:// maryknollafrica.org/Documents/Resources \%20for\%20the \%202009\%20Second\% 20African\%20Synod.htm, Proposition no. 47.

${ }^{24}$ Kwame Bediako celebrates the demographic shift of Christianity to the global South in Christianity in Africa: The Renewal of a Non-Western Religion (Maryknoll, N.Y.: Orbis, 1995); Philip Jenkins does the same in The Next Christendom: The Coming of Global Christianity (New York: Oxford University, 2002). Recently Allen (Future Church 13-53) has demonstrated how the staggering growth of African Christianity appears as one of the defining trends of global Catholicism. 
remains elusive in the face of religious exuberance in Africa. This realization questions the sustainability and credibility of faith in Africa under the current dispensation.

In the context of Africa, the argument for the contribution of Christianity and other religions to development about which Pope Benedict waxes persuasively cannot be assumed a priori and axiomatically. To his credit the pope sounds a cautionary note: "While it may be true that development needs the religions and cultures of different peoples, it is equally true that adequate discernment is needed" (no. 55). Besides religious fundamentalism several reasons can be adduced for questioning the relevance of religion, as practiced presently on the Continent, to development, but none is more blatant than the proliferation of the "gospel of prosperity" in several parts of Africa. Briefly stated, this "gospel" equates "faith" with "prosperity" by claiming that the abundance of the former guarantees access to the latter in the form of material success, wealth, fertility, and social status, irrespective of prevalent contextual considerations. ${ }^{25}$ Here is an area that stands to benefit from the principles of Catholic social teaching on the structural causes of poverty, such as the negation of human rights, corruption, and the assault on the dignity of the human person by unjust socioeconomic and political arrangements. The situation in Africa demonstrates that, divorced from charity and truth, religion resembles a double-edged sword capable of inflicting permanent damage on the development of peoples. ${ }^{26}$

25 Useful materials on the gospel of prosperity in Africa include: Paul Gifford, "Prosperity: A New Foreign Element in African Christianity," Religion 20 (1990) 373-88; Gifford, African Christianity: Its Public Role (Bloomington: Indiana University, 1998); Rosalind I. J. Hackett, "The Gospel of Prosperity in West Africa," in Religion and the Transformations of Capitalism, ed. Richard H. Roberts (London: Routledge, 1995) 199-214; James F. Ndyabahika, "The Attitude of the Historical Churches to Poverty and Wealth: A Challenge for African Christianity," Africa Journal of Evangelical Theology 23.2 (2004) 199-214; David T. Williams, "The Heresy of Prosperity Teaching: A Message for the Church in Its Approach to Need," Journal of Theology for Southern Africa 61 (December 1987) 33-44; Karl Maier provides a vivid account of how the gospel of prosperity preys on the gullibility of African elites and the desperation of the African poor, especially women, in This House Has Fallen: Nigeria in Crisis (London: Penguin, 2000) 251-67. A related phenomenon is the tendency among religious leaders in Africa to cultivate close links with key figures of the political establishment; see Jeff Haynes, Religion and Politics in Africa (Nairobi: East Africa Education, 1996).

26 There are notable instances where the Church is a positive agent of development in Africa. These examples should temper the view that religion often hinders integral development. "If one wanted to sum up in one word the role of Kenya's Catholic Church, it would be development. Blessed with enormous resources, educated personnel and extensive grassroots networks, the Catholic Church is a development agency without parallel. Development extends to every activity, although schools and hospitals are still the most obvious" (Paul Gifford, Christianity, Politics, and Public Life in Kenya [London: Hurst, 2009] 81). For a more comprehensive and 


\section{STATE-BUILDING AND DEVELOPMENT}

Besides religion, Caritas in veritate critically analyzes the role of the state in economic development, arguing for a harmonious interaction of the state, private sector, and civil society. Here, as in other areas, the encyclical draws on a variety of political and philosophical theories about the meaning, function, and rationale of the state as an independent and irreplaceable entity. In addition to the critical importance of the state in the pursuit of integral development (nos. 24-25, 28, 38-41), Benedict rightly notes the impracticality of demarcating boundaries of states as impervious lines in the context of an aggressive process of globalization of international labor, trade, and finance. Globalization could weaken the functionality of the state by operating along an economic, social, and political trajectory that escapes and defies the oversight of state actors.

Despite assuring signs of improvement, the concept of statehood in Africa is as weak as it is precarious. It is hard to establish a stable concept of state in the context of Africa's 53 independent states. ${ }^{27}$ Patrick Chabal and Jean-Pascal Daloz sum up this point somberly: "In most African countries, the state is no more than a decor, a pseudo-Western façade masking the realities of deeply personalized political relations." 28 The relatively large number of fragile, unstable, and failed states partly accounts for Africa's underdevelopment. In instances where democratic principles are subordinated to narrow political interests, the state and its public authorities metamorphose into potent means of plunder, exploitation, and misappropriation of economic resources. Among the triadic complex of market, state, and civil society advocated by John Paul II and reiterated by Benedict XVI, in Africa, the state remains the most volatile and potentially lethal element in need of renewal and civilization (see no. 38).

\section{CONCLUSION}

Notwithstanding the analytical density of Caritas in veritate, the encyclical is particularly refreshing for the breadth of its scope, the depth of its philosophical and theological arguments, and, above all, its emphasis on

positive appraisal of the contribution of faith-based organizations and churches in Africa to development, see Deryke Belshaw, Robert Calderisi, and Chris Sugden, eds., Faith in Development: Partnerships between the World Bank and the Churches of Africa (Oxford: Regnum, 2001).

27 See Jean-François Bayart, Stephen Ellis, and Béatrice Hibou, The Criminalization of the State in Africa (London: International African Institute, 1999); Chabal and Daloz, Africa Works 3-16. George B. N. Ayittey, Africa in Chaos (New York: St. Martin's Griffins, 1999) 149-84, likens the institution of state in Africa to a "vampire" for reasons of its exploitative and oppressive tendencies.

28 Chabal and Daloz, Africa Works 16. 
generating inclusive practical solutions rather than abstractions and speculations in the domain of development: "Solutions need to be carefully designed to correspond to people's concrete lives, based on a prudential evaluation of each situation. Alongside macro-projects, there is a place for micro-projects, and above all there is need for the active mobilization of all the subjects of civil society, both juridical and physical persons" (no. 47). Nowhere is this message more relevant than on the continent of Africa.

As I have demonstrated here, without overlooking points of divergence, several elements of Caritas in veritate converge to suggest certain priorities for action relative to the Continent's tumultuous quest for integral development. Taken as a whole, and considered in its multiple aspects, this encyclical outlines the kind of development suited for Africa: "inspired by charity and placed at the service of truth" (no. 73), and founded on the principles and virtues of human dignity, justice, global solidarity, and shared gratuitousness. 